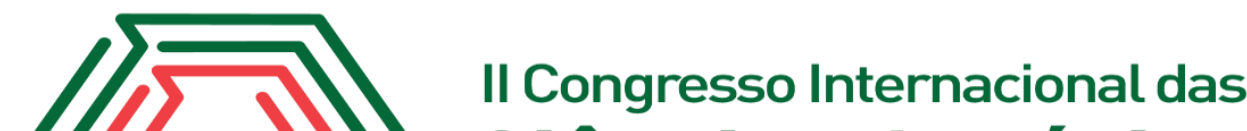 Ciências Agrárias COINTER - PDVAgro 2017
}

\section{HERBÁRIO COMO FERRAMENTA DE ENSINO PARA IDENTIFICAÇÃO CORRETA DE ESPÉCIES DE PLANTAS DANINHAS NA REGIÃO DE CODÓ- MA}

Apresentação: Relato de Experiência

\author{
Ayane Lima Ferreira ${ }^{1}$; Maria Roselane Alves Oliveira $^{2}$; Cristiane Nunes da Conceição ${ }^{3}$; Gutierres \\ Nelson da Silva ${ }^{4}$
}

\section{Introdução}

A base para a formulação de uma eficiente proposta de controle de plantas daninhas é a identificação da flora que ocorre nas áreas de produção (ADEGAS et al., 2010). Essas informações podem ser conseguidas por meio de um herbário. Herbário trata-se de uma seleção de plantas secas que tem por finalidade catalogar cientificamente a flora de uma determinada região. Um herbário com fins educativos é denominado herbário didático, visando auxiliar o ensino de áreas voltadas para botânica complementando dessa forma o processo de ensino-aprendizagem. Serve como um laboratório multidisciplinar onde os alunos aprendem técnicas de coleta, prensagem, secagem e montagem das amostras botânicas, no caso de plantas daninhas. (SANTOS, 2003). Diante do exposto, objetivou-se com este estudo a observação "in loco" de como um herbário didático pode auxiliar o desenvolvimento cognitivo nas aulas de Biologia, controle e identificação de plantas daninhas, para o curso de Agronomia.

\section{Relato de Experiência}

A experiência foi realizada no município de Codó, MA, localizado na mesorregião do Leste Maranhense, no Instituto Federal de Educação, Ciência e Tecnologia do Maranhão, Campus Codó. As atividades de montagem de herbário foram realizadas no segundo semestre de 2016, na disciplina, Biologia, controle e identificação de plantas daninhas, ministrada pelo professor Gutierres Nelson da Silva. A atividade foi realizada em duas fases: na primeira, o professor trabalhou a parte teórica, explanando as principais espécies de plantas daninhas e sua importância agronômica. Já na segunda fase foi proposta uma atividade prática com a montagem de herbário com plantas daninhas. As coletas das plantas daninhas foram realizadas nas imediações do Campus e em propriedades de pequenos produtores da região.

\footnotetext{
${ }^{1}$ Agronomia,IFMA, ayaneagro14@gmail.com

${ }^{2}$ Agronomia,IFMA,roselany.alves@hotmail.com

${ }^{3}$ Agronomia,IFMA,cristianenunes2996@gmail.com

${ }^{4}$ Doutor,IFMA,gutierres.nelson@ifma.edu.br
} 
Exigiu-se para cada herbário um quantitativo de 20 diferentes plantas daninhas. As plantas selecionadas eram de porte pequeno as quais deveriam ser retiradas juntamente com a raiz. Após esse procedimento, as plantas foram prensadas e secas naturalmente. Depois da secagem prepararam-se as exsicatas com suas devidas etiquetas contendo nome cientifico, nome popular e família. A identificação das espécies foi realizada baseada no Manual de identificação e controle de plantas daninhas plantio direto e convencional de Harri Lorenzi (2014). No meu herbário foram colecionadas a seguintes plantas daninhas:

\begin{tabular}{|l|l|l|}
\hline Família & Nome Científico & Nome Comum \\
\hline Euphorbiaceae & Chamaesyce spp & Erva-de-Santa-Luzia \\
\hline Phyllanthaceae & Phyllanthus spp. & Quebra-pedra \\
\hline Amaranthaceae. & Amaranthus deflexus L. & Caruru rasteiro \\
\hline Polypodiaceae & Nephrolepis polypodium & Samambaia \\
\hline Euphorbiaceae & Euphorbia próstata & Quebra- pedra rasteiro \\
\hline Fabaceae & Mimosa spp. & Falsa dormideira \\
\hline Poaceae & Eleusine indica & Pé-de-galinha \\
\hline Cyperaceae & Cyperus iria & Tiririca \\
\hline Lamiaceae & Eriope tumidicaulis & Hortelã \\
\hline Convovulaceae & Ipoema spp. & Corda-de-viola \\
\hline Portulacaceae & Talinum paniculatum & João Gomes \\
\hline Commelinaceae & Commelina benghalenensis & Trapoeraba \\
\hline Euphorbiaceae & Euphorbia heterophylla L. & Leiteira \\
\hline Poligonáceas & Polygonum hydropiper & Pimenta-d'água \\
\hline Gramineae & Digitaria sanguinalis & Capim colchão \\
\hline Capparidaceae & Hemiscola aculeata & Mussambê \\
\hline Malvaceae & Triumfleta rhomboidea & Guanxuma \\
\hline Thelypteridaceae & Thelypteris rhomboidea & Samambaia-do-mato \\
\hline Portualacaceae & Portulaca oleraceae) & Beldroega \\
\hline Malvaceae & Sida santaremnensis & Guanxuma-grande \\
\hline
\end{tabular}

\section{Considerações}

Ao longo da disciplina, pode-se observar que os acadêmicos do $6^{\circ}$ período de agronomia se mostraram motivados para coletar as espécies em campo, demonstrando que o herbário serviu como uma ferramenta de ensino para identificação correta de espécies de plantas daninhas.

\section{Referências}

ADEGAS, F. S. et al. Levantamento fitossociológico de plantas daninhas na cultura do girassol. Planta Daninha, v. 28, n. 4, p. 705-716, 2010.

Santos, M.C.F. 2003. O herbário como material didático para o ensino de Ciências e Biologia. Pp.292-295. In: II Encontro Regional de Ensino de Biologia: Formação de professores de Biologia: articulando universidade e escola. Niterói, SBEnBioRegional 02.

Lorenzi, H.Manual de identificacao e controle de plantas daninhas : plantio direto e convencional/.-7.ed.-- Nova Odessa, SP: Instituto Plantarum, 2014. 